Szántó, Ildikó. "Hungarian Population Discourses in the Twentieth Century: The Problem of Declining Birth Rates." Hungarian Cultural Studies. e-Journal of the American Hungarian Educators Association, Volume 8 (2015):

\title{
Hungarian Population Discourses in the Twentieth Century: The Problem of Declining Birth Rates
}

\section{Ildikó Szántó}

\begin{abstract}
Falling birth rates had already been recorded as early as the late-eighteenth century in south-western Hungary in the Ormánság. Population loss from low birth rate remained one of the main topics writers and sociologists focused on in the twentieth century. The issue of Hungarian population decline was highlighted among the social ills in the interwar period, which was one of several subjects that divided intellectuals into "populists" and "urbanites." Following the impact of the low birth rate figures in the 1960 s, the populists' views of the 1930s resurfaced in public discourse in the 1960s and 1970 s and up to the present day. The concern about the increasing trend of single-child families in rural settlements as well as in urban areas appeared in the various works of Hungarian writers and journalists throughout the previous century. The present paper intends to focus on the intellectual background to the public debates on the population issue, outlining the accounts of the interwar "village explorers" briefly, and the way they are related to the pre-Second World War populist movement. Finally the reappearance of the debates between populists and non-populists of the 1970s is discussed, a debate that is still continuing.
\end{abstract}

Keywords: Low Birth Rates, Single-Child Families, Hungarian Populism, Population Loss

Biography: Ildikó Szántó received her M.A. degree in History from Macquarie University, N.S.W. She has taught interdisciplinary courses focusing on the ideological movements of the twentieth century in East-Central Europe at the Budapest University of Economic Sciences, Pázmány Péter Catholic University, and the Budapest Business School.

This article is a continuation of a previous paper in which I outlined that, for over a century, Hungary has had a seriously declining birth rate. I focused on four major periods: the first prior to the demographic transition that commenced before 1880; the second, the period of demographic transition between 1880 and 1960 coinciding with modernization; the third was the post-transitional era of 1960-1980; and finally the post-socialist change of 1990-2010 (Szántó 2014).

The enormous death toll of the First World War, accompanied by its economic crisis, followed by the traumatic effect of the Treaty of Trianon with the loss of one third of the native Hungarian population, left an indelible mark on Hungarian national consciousness. The First 
Szántó, Ildikó. "Hungarian Population Discourses in the Twentieth Century: The Problem of Declining Birth Rates." Hungarian Cultural Studies. e-Journal of the American Hungarian Educators Association, Volume 8 (2015): http://ahea.pitt.edu DOI: 10.5195/ahea.2015.215

World War also resulted in a sharp decline in births throughout Hungary, while the "catching up" period after the war, when fertility rates were usually high in other countries, proved to be relatively short; too short to indicate a marked increase in fertility figures (Ránki 1978: 766-767). In addition to the general decrease in live births, there were certain Transdanubian regions such as the Ormánság which showed continuous lower fertility rates than the national average for decades before the First World War (Andorka 1987: 334.).

There were two main reasons for the falling birth rates in Ormánság in south-western Hungary. One was rooted in economics, namely the fear of poverty, whilst the other was an adoption of a new value system based on birth control. Initially a small number of children per family became the norm, but this soon developed into a custom of having a single child only, the "egyke," as fertility limitation was the answer to avoiding subdivision of inherited land. The peasant landholders in the Ormánság villages were well-off in the1800s as they had more common land and forests than previously, but by the 1880s these lands were expropriated or legally restored to the surrounding large landowners. The shortage of available land made them act so as to avoid the plight of landlessness. Consequently, birth control within marriage and the practice of crude abortions, which were often carried out by members of the family, became widespread in the region (Buday 1909:15, Andorka 1969: 26).

Accounts on deliberate birth control in Ormánság and in Baranya County were reported in three different periods, firstly in the eighteenth century, secondly in the late-nineteenth century, and finally in the interwar era. Initial falling birth rates had been recorded in the Ormánság where an anonymous public servant commented on the census of 1777 and enclosed his findings, stating that "four couples hardly produce a child a year..." (Dányi 1960: 172, 184). Beyond a doubt, he said, the reason for this was that "the parents realized their inadequate means of feeding and providing for the offspring and putting aside God`s law in the sexual act of marriage, they prevent conception and procreation" [a szülök, átérezve nagyobb számú sarjadék táplálására való elégtelenségüket és ivadékainak jövendö szükségét, az isteni törvény szigorát mellözve magában a házassági aktusban a fogamzást és nemzést akadályozzák] (Dányi 1960: 188).

In the 1840s, Miksa Hölbling, Chief Physician in Baranya County, who recorded live birth rates separately in both the Calvinist and Catholic villages, noted that birth rates were higher in the Catholic German (Swabian) villages in comparison with the Calvinist Hungarian ones. According to his accounts, Hungarian villagers considered it shameful for a woman to give birth to a child in the first four years of her marriage, and even the healthiest women rarely gave birth to more than two children (Hölbling 1845: 62, 64, cited in Andorka 2001:14). Initially, Hölbling blamed this practice on the vanity of Hungarian peasant women, who wanted to keep their youthful figures, rather than raise a family, but he soon realized that the real cause of birth control was rooted in economics, which stemmed from the lack of available land and in the practice of apportioning property among heirs. Hölbling's accounts of different birth rates between Hungarian and German villages, as well as the different inheritance customs of Hungarian and German peasant landholders, led him to the conclusion that eventually the Hungarian peasant population in Ormánság would be taken over by German settlers, who had already changed the ethnic map of this formerly entirely Hungarian region (Hölbling 1845: 8586). Concurrently, in 1843, the agricultural periodical Magyar Gazda ['Hungarian Farmer'] also published an account of population decline in the northern counties of Nógrád, Bars, and Hont, where in certain villages the clergyman rebuked the midwives who aided or carried out abortions (Kókay 1979: 481). In addition to Hölbling's accounts, there were several articles and reports on 
Szántó, Ildikó. "Hungarian Population Discourses in the Twentieth Century: The Problem of Declining Birth Rates." Hungarian Cultural Studies. e-Journal of the American Hungarian Educators Association, Volume 8 (2015): http://ahea.pitt.edu DOI: 10.5195/ahea.2015.215

the low birth rates in other Transdanubian areas beside Ormánság, such as Baranya, Tolna, and Somogy where deliberate termination of unwanted pregnancies were reported (Széchenyi 1906: 70, Höke cited in Andorka 2001: 13-16). Nevertheless, it was Hölbling who raised the essential features of the low birth rate, its economic and moral causes, as well as the possible differences between nationalities and denominations.

The second "egyke" discourse in the 1900s also focused on the south-western Transdanubian villages, based on the statistician Dezső Buday's state-funded research to explore the causes of birth control in regions where it was suspected that it was being practiced. Buday used census data from between 1869 and 1900 based on live births, mortality, the number of children under the age of six, and the number of school age children. He sent comprehensive questionnaires to each village council, and asked the peasant landholders what they thought were the reasons for having only one child and how the low birth rate could be redressed. Buday compared three regions in Baranya: the predominantly Calvinist and Hungarian Ormánság, the mostly Catholic and German Mecsekalja, and the religiously and ethnically mixed area around the town of Mohács in southern Hungary, proving that single-child families occurred in all these areas irrespective of religion or ethnicity. In the summary of his research Buday highlighted that the shortage of available land was the primary reason given by the peasants for having an "egyke" (single-child) family. The peasant landholders argued that even in villages where peasants owned twenty-two to twenty-five Hungarian acres on average, the living standard of the next generation would be much affected once the land was subdivided among three or four children. The practice of birth control was expressed in the saying: "One quarter of a plot, one child, we plow but do not sow" [Egy fertály, egy gyerek, Szántunk, de nem vetünk] (Buday 1909: $3,8)$. In other words, the fear of poverty by small and middle peasant landholders was the reason to keep the land for only one heir. The responses given to Buday's questionnaires also included the need for government assistance, leasing arrangements, and availability of loans for intensive and market-oriented agriculture - all of which could improve the prospects of small and middle peasant landholders. The fact that the Ormánság villages were surrounded by entailed large properties meant the lack of purchasable land, which left not much alternative for the small and medium landholders other than the custom of birth control during marriage (Buday 1909: 145, see also Jászi 1909: 3-17, Romsics1999: 190-199).

Buday's research coincided with and was part of a heterogeneous movement, an intellectual ferment, centered around the newly established modern literary periodicals Nyugat ['The West'] and the Huszadik Század ['Twentieth Century']. These liberal periodicals, together with The Sociological Society founded by Oscar Jászi, were the main forums for sociological issues with democratic aims prior to 1919 (Jászi 1909: 3, Litván and Szücs 1973: 103, Congdon 1976: 169). The poet Endre Ady, who also shared the liberal and democratic views of Jászi, commented on the low birth rate in 1906: "A whole nation is dying" [Haldoklunk]."People do not want to be born. They migrate, even if they decide to live. People do not want to get married. People are afraid to have offspring. People are in a hurry to die, because they cannot find a way to live. This is the national progress" [Az emberek nem akarnak megszületni. Az emberek elmennek innen, ha már élnek. Az emberek nem házasodnak. Az emberek óvakodnak az. útodoktól. Az emberek sietnek meghalni, mert nincs mód élni. Ez a nemzeti föllendülés] (Vezér 1977: 277). 
Szántó, Ildikó. "Hungarian Population Discourses in the Twentieth Century: The Problem of Declining Birth Rates." Hungarian Cultural Studies. e-Journal of the American Hungarian Educators Association, Volume 8 (2015): http://ahea.pitt.edu DOI: 10.5195/ahea.2015.215

The 1920 census revealed that the birth rate was significantly lower in certain regions where birth control was presumably practiced, such as in the primarily Catholic Transdanubian villages in Somogy and Sárköz, the Catholic German villages of the south, Banat (BácskaBánát), the Greek Orthodox Romanian villages of Caras-Severin (Krassó-Szörény) and Hunedoara (Hunyad). Thus, the census figures reinforced the earlier pre-1914 findings, that the Protestant Hungarian peasant farmer was just as concerned about the size of his family as the Catholic German or the Greek Orthodox Romanian small peasant landholder, and that regardless of denomination all practiced birth control (Demény 1972: 165).

The third "egyke" discourse was sparked by way of a literary publication, János Kodolányi’s short story, Sötétség ['Darkness'] in 1922. Kodolányi depicted the harrowing event in a village of Baranya, in Ormánság, where a young woman was forced against her will to follow the example of other young wives in the village. When the makeshift abortion failed, she ended up dying, but not before having to listen, in her last hour of agony, to her funeral arrangements. Although there was an official response to the acute problems of the shrinking Ormánság villages, this chiefly emphasized the decline in moral values of the peasantry and their lack of religiousness; officialdom disregarded economic and social aspects of the villages (Pezenhoffer 1922: 243-247, Kovács 1923: 15). In contrast to the official views, the novelist Kodolányi, who spent his formative years and his first employment as a young teacher in Vajszló, was familiar with the distorted world of the Ormánság, a region where young married women were forced by their elders not to bring a child into the world. He pointed out the real cause of "egyke" in his famous memorandum of 1927 titled "A hazugság öl" ['Lying kills'] addressed to the Deputy Prime Minister. In it he condemned the system of landed estates as the direct cause of "egyke" and identified the economic ills of the country, ills that required profound political changes (Kodolányi 1987: 14).

Kodolányi's impassioned memorandum was followed by the scholar and clergyman Lajos Fülep's articles in the liberal-conservative daily Pesti Napó on the economic causes of population decline in Baranya, Tolna, and Somogy counties. It was also Fülep who wrote: "our current adversaries are the single-child family, emigration, tuberculosis and all the other associated moral and economic ills" (Fülep 1929). He traced the "egyke" problem to the loss of the allodial lands in the nineteenth century, and to the fact that the small and medium landholders were in the iron grip of landed estates (Fülep 1933: 281-287). Beside Fülep, there was another Calvinist pastor, the ethnographer Géza Kiss, who without any government assistance examined the demographic evolution of forty-five villages over two centuries, and arrived at the same conclusion as had Fülep, that lack of land, the distant markets, the backwardness of agricultural methods and above all the fear of impoverishment were the underlying causes of "egyke". He documented the same situation as Buday had earlier, "one household and one child," the custom that led to the depopulation of once prosperous villages (Kiss 1986:504-506).

Fülep, who bridged prewar and interwar liberal thinkers, echoed Buday's warnings about the fate of the Transdanubian villages, namely that their original Hungarian population would disappear (Fülep 1929: 11-12). Though Fülep played a major role in the genesis of Hungarian sociography, the movement of village exploration, it was the article by Gyula Illyés titled Pusztulás ['Disappearance'] which focused the public's attention on the single-child family and started the third discourse on the Transdanubian Hungarian population decline. Illyés was one of the well-known young writers of the 1930s who shared the strong sociological interest and left- 
Szántó, Ildikó. "Hungarian Population Discourses in the Twentieth Century: The Problem of Declining Birth Rates." Hungarian Cultural Studies. e-Journal of the American Hungarian Educators Association, Volume 8 (2015): http://ahea.pitt.edu DOI: 10.5195/ahea.2015.215

wing convictions of the so-called "népi" ('from the people') writers. Following an invitation from Fülep, Illyés turned his attention to the "egyke" issue in Baranya and Tolna.

Illyés vividly portrayed the unfolding tragedy of Ormánság, the "egyke," as he referred to earlier accounts of a formerly prosperous, hard-working, healthy, and community-minded population turning into a sickly, inward looking group of individuals. He wrote about villages, where land and property were increasingly neglected, where money was gained and lost quickly at the card tables and where neuroses and alcoholism had become as prevalent as tuberculosis elsewhere in Hungary. In one of his visits, a young peasant farmer expressed his views on having a family and said the following to Illyés: "We won't produce beggars-... The country is full of unemployed people, there are more people than we need, so what do you want from us? Give us land and the land will produce more people" [Nem csináljunk kódisokat-mondta ...Az ország tele van munkanélkülivel - több ember van, mint kellene, mit akarnak mitölünk? Adjanak földet, a föld maga megtermi az embert] (Illyés 1933: 189). Illyés quoted Buday's research, stating that in most cases the villages were bordered by eighty to hundred thousand acres of landed estates where the peasants could not rent land or obtain work, not even as day-laborers. The peasant villagers told him "there is no land...no life... why should there be so many people...here is the large estate" [Nincs föld... Nincs élet... Mire az a sok ember?... Itt a nagybirtok] (Illyés1938: 15).

In contrast to the German-populated villages of medium-size landholders, the Hungarian villages were predominantly in the vicinity of the largest estates. According to Illyés, the birth rate of the German-speaking peasant population in Somogy, Tolna, and Baranya counties was significantly higher than in the Hungarian villages, and as these counties made up half the area of Transdanubia, he feared that the Hungarian population would soon become a minority. While Fülep's earlier articles were ignored in the capital, Illyés succeeded in alarming public opinion about the falling birth rate and the long-term impact of the "egyke," as well as the effect of the higher German birth rate that could endanger Hungarian identity and language (Illyés 1933: 338).

The publication of Illyés' Pusztulás had a two-fold effect. First, it polarized writers into two groups, as it split the so-called second generation writers of the modern literary periodical, Nyugat into nationals or "populists," who were the "népi" ['peoples'] writers and the "urbanites," or liberals. The second impact was the birth of sociography, the village exploration movement. Illyés' passionate claim about the eventual disappearance of the Hungarian population sparked an intense debate on the subject of "vanishing" Hungarians as well as on Hungarian language and culture (Babits 1933: 269-272). The Nyugat writers, such as Aladár Schöpflin or Illyés, could not be accused of chauvinism, though there was a reference in the Nyugat that questioned the cultural loyalty of the "assimilated Hungarians," which meant the German and Jewish population. It was a sensitive issue when assimilated Germans and their descendants made up fifteen to twenty percent of the educated middle class and that the close to six percent of assimilated Jews played a pivotal role in Hungarian modernization (Lendvai 2002: 354, Schöpflin 1933: 272). Concurrently, with the sociological reportage of the village explorers, Illyés' Puszták Népe ['People of the Puszta'] was a significant contribution to the literary aspects of the discourse. In this autobiographical work, Illyés depicted the merciless, semi-feudal conditions of the large Transdanubian estates, the "puszta," which meant a conglomeration of dwellings, which frequently sheltered one or two hundred families and were separated from the village community, while being exploited at the whims of the landowners or the estate managers. It was a place where corporal punishment was taken for granted just as much as ius primae 
Szántó, Ildikó. "Hungarian Population Discourses in the Twentieth Century: The Problem of Declining Birth Rates." Hungarian Cultural Studies. e-Journal of the American Hungarian Educators Association, Volume 8 (2015):

noctis ['the right of the first night'] by managers or by those in power (Illyés 1993: 87-89, 135145).

Similarly to Illyés, the majority of the "népi" writers were either from a peasant background or in close contact with rural life; they were also people who participated in the village exploration movement that was part of the Hungarian populist movement. The movement was characterized by a patriotic sentiment and was concerned primarily with the state of the peasantry. Most of the "népi" writers, who also shared an anti-capitalist outlook, viewed the peasantry as the backbone of the nation, which would be capable of the political and cultural revival of Hungary if given the opportunity. Following the split of the populists and the "urbanites," the "népi" writers published their sociographical literature in Válasz ['Response'] and Kelet Népe ['People of the East'] from the mid-1930s on, instead of in the more literary periodical Nyugat. At the same time, Szép Szó ['Fine Words'], the independent literary journal of the "urbanites," was founded, which centered around the poet Attila József. This publication stood for universal democratic values above national issues, although it was also committed to the "have nots." In contrast to the populists, the "urbanites" perceived the unsolved Hungarian problems, not merely in terms of the low birth rate, but in a larger context as well. They compared the backwardness of Hungary to western European progress and development (Braun 1933: 279).

The unresolved economic and social issues of the peasantry, that is of more than half the population, remained in the forefront of political and intellectual debates. Following Illyés' articles and the Nyugat debate, there was a burst of publications not only about demographic issues, but generally about the underdevelopment of the countryside. In contrast to Transdanubian demographic reports, Zoltán Szabó depicted the deprivation of large families in the North-Eastern Hungarian villages, especially in the Matyó land, where the poverty of the dwarf landholders and landless peasants in Mezökövesd, Tard, and Szentistván was stark. Their splendidly embroidered Matyó aprons and blouses disguised the peasants' misery, namely that every fourth new-born died in his first year, and that the north-eastern Hungarian counties had the highest rate of infant mortality and tuberculosis in Hungary (Szabó 1937: 233, 1938: 72-73). Similarly, in the south-east corner of Hungary, on the left bank of the river Tisza, mortality figures were just as alarming as Szabó's account of the north-east. According to Féja, who described the agrarian problems of "Viharsarok" ('Stormy Corner') in the south-east of Hungary, the custom of single-child families spread to the south-east too, where it had been unknown previously (Féja 1937: 221, 1984: 45).

Generally in the interwar period, sociography as a discipline was closer to literature than social science, with the possible exceptions of the publications of the politician Imre Kovács, the medical practitioner János Hidvégi, and the sociologist Ferenc Erdei. Kovács, Hidvégi, and Erdei relied on statistical data and gave a detailed account of the economic and social problems in the Transdanubian and south-eastern counties. Kovács, who studied the demographic patterns of the Ormánság villages, also observed that after two generations there was another effect of the continued use of birth control; it became accepted behavior that the older women and mothers ruled the households. A matriarchal system evolved where the subordinated sons-inlaws, who often came from other villages and were despised for their poverty, became servants in their own households. In the distorted world of Ormánság, marriage came to mean uniting two properties for one descendant. The description of the new value system and a new code of behavior based on strict birth control portrayed the hopelessness of the existing situation (Kovács 1937: 33, 36, 147). Kovács also advocated land reform instead of emigration, religious 
Szántó, Ildikó. "Hungarian Population Discourses in the Twentieth Century: The Problem of Declining Birth Rates." Hungarian Cultural Studies. e-Journal of the American Hungarian Educators Association, Volume 8 (2015): http://ahea.pitt.edu DOI: 10.5195/ahea.2015.215

sectarian movements, or crude birth control. Beside Kovács, Hidvégi, who also researched the Ormánság region independently without any government support, indicted the existing "liberalcapitalist system" which ignored the peasantry. He quoted the often heard views of his patients: "couldn't she be more careful... if I bred so many, I'd die of shame" or "my old szüle (the grandmother) will advise me when to wash the sheets rather than nappies" [Hát nem tud vigyázni...nekem kisütt vóna a szemem, ha ennyit kölkeztem vóna, és az öregszüle rendesen tanácsolja, hogy inkább lepedöt mossál,mint pelenkát] (Hidvégi 1938: 63). Hidvégi also observed the appearance of a new value system whereby the villagers felt some sympathy for a barren woman, but those who had more than two children became a subject of scorn and contempt. As a medical practitioner, he commented on the health of women who often became crippled by their middle age, sickly looking and bent, seeing these symptoms as related to the harsh abortion practices (Hidvégi 1938: 63).

Kovács and Erdei were also sociologists who analyzed the agrarian problems beyond the issue of the spread of single-child families and argued for more than land reform: in their opinion, Hungarian semi-feudal agrarian life was doomed, and social renewal was inevitable (Kovács 1940: 5, Erdei 1938: 36, 142-143). Erdei contrasted the Hungarian socially stratified, economically backward peasant society to the technologically and socially advanced Western European peasant citizens (Erdei 1938: 14-15, 138, 191, Bibó 1982: 329). He not only destroyed the romantic myth of village life, but also stressed the need for urbanization, which meant that the peasantry would cease to be a major source of offspring (Erdei 1940: 142-143, 206-207). Erdei saw the "egyke" single-child family as the symptom of the hopelessness of traditional peasant life. The practice was a response to a situation to which they could not find an alternative to any other forms of existence: "they had enough of a peasant's life, but...they are not escaping. Stubbornly staying put to gain a footing and they deny life itself" [elég volt a paraszti életböl, de...nem menekülnek. Megátalkodottan megvetik a lábukat, és az életet magát tagadják meg] (Erdei 1973: 177). Prior to 1945, Erdei formulated the clearest conceptions and theories in Hungarian social science. His major works on the peasantry of the Alföld (Great Plain) in Eastern Hungary and the area between the rivers Danube and Tisza as well as the central Hungarian market towns remained primary sources of peasant life in the interwar period (Erdei 1941: 197).

The government reaction to the "egyke" was one of indifference, claiming that demography was not a field in which writers and poets should dabble. Similarly to the official view, Kuno Klebelsberg, the Minister of Education, attributed the spread of single-child families to Protestantism as well as to the immorality of the countryside, and urged women to take motherhood more seriously. However, there was a stronger response to the publications of Kovacs' and Feja's works, as both books were banned and the authors were imprisoned on charges of inciting revolution (Andorka 2001: 23, 29). It was apparent that fundamental land reform remained anathema to the Hungarian political elite in the interwar period when more than seventy percent of the peasantry owned only ten percent of the agricultural land. Consequently, the exploration of the economic ills of the countryside was left to the sociographers and writers, while the inability of the political elite to commit to progress were largely responsible for Hungary's deep-rooted economic and social problems. Politicians continued to turn a blind eye to the economic causes of single-child households (Bodó 2001:189).

In addition to the economic crises of the 1930s, there was an external threat too, as Hitler's pan-German and racially superior sentiments found support in Hungary from the 1930s 
Szántó, Ildikó. "Hungarian Population Discourses in the Twentieth Century: The Problem of Declining Birth Rates." Hungarian Cultural Studies. e-Journal of the American Hungarian Educators Association, Volume 8 (2015): http://ahea.pitt.edu DOI: 10.5195/ahea.2015.215

on (Babus 2002: 4). By the end of the 1930s, the populists or "népi" writers were represented at both ends of the political spectrum: as members of the left wing (as socialists), as well as members of the right radicals. Féja and Kodolányi, who originally belonged to the left, supported anti-Semitic views by the end of the 1930s. Others professed various shades of political views of the left, which included the short lived anti-fascist March Front between 1937 and 1939 (Kemény and Sárközi 1982: 252-254). There were also major representatives of the "népi" movement in the center of the political spectrum, such as István Bibó, László Németh, and Zoltán Szabó, who advocated a "third path" and hoped to form an alliance between the middle classes and the peasantry (Ránki 1978: 844-845). The populist movement dispersed by the early 1940s but the literary debates between "populists" and "urbanites" polarized participants, since a significant number of the "urbanites" had Jewish backgrounds. Fülep, and to a lesser degree Illyés, were the exceptions who remained outside of the populist-urbanite dispute (Vas 1984: 66-88, Babus 2002: 6-9).

After 1948 there were no forums for liberal or conservative views except for a short period in 1956. The first public discussions began between 1957 and 1964, when vast social and economic changes were carried out in the Hungarian countryside, which in turn affected the family, the smallest social unit (Cseh-Szombathy 1978: 34-35, Szabady 1971: 57 in Löcsei). Among the many debates, the one on the low birth rate was the most important and the longest between 1963 and 1968. The disclosure of the 1960 birthrate figures indicated that the level of fertility had dropped below the simple replacement of the parent generation, which sparked three public discourses before 1990 (Potó 1986: 26, KSH 1978: 186, Szabady 1961:15). The journalist Ambrus Bor was among the first populist writers who argued that with an increased standard of living a higher birth rate was expected, whilst in fact the opposite took place in Hungary (Bor 1963a, 1963b). At the same time, Kodolányi revisited the Baranya villages of his childhood and reported that Hungary could become a great Besence, a village of single-child families losing its original population (Kodolányi and Kodolányi Jr. 1976: 229). In the following years a large number of articles appeared in the literary weekly, ÉS, and in dailies and weeklies as well as in academic journals. The press debates highlighted some of the major problems of society, such as the acute housing shortage, the disintegration of rural communities, concerns of commuters, the lack of flexible working hours for women, and generally the financial burden of families with children. The public discussion was also a severe criticism of the lack of social policy on the part of the government in relation to other socialist countries (Veres 1964a:14, 1964b: 1609-1610).

The majority of leading participants of the first debate were from the "népi" writers or populists of pronatalist sentiments, such as the writer Péter Veres, and journalists, including Bor, Károly Jobbágy, Gyula Fekete and Éva Bozóky, who primarily focused their argument on the long term impact of the low birth rate and the concomitant shortage of labor power, and criticized the young generation for their irresponsibility in abandoning traditional family values for instantaneous pleasure. The populists maintained that having a family was both an economic and national issue, while at the same time there was veiled criticism of the socialist political system, which did not limit consumerism and individualism (Bor 1963a:721-731, 1963b:5, Jobbágy 1964:5, Fekete 1964:5-6, Bozóky 1964a:7-8, 1964b:5-6, 1964c:3). Though the populists formed a common platform in the debate on national concern, the women participants of the first debate, such as Bozóky, Judit Máriássy, or Piroska Szenes, joined the discussion with certain reservations. The women contributors were all working mothers also who tried to accommodate work and family, while firmly believing that a woman's duty was to have children, but disagreeing with the populists' male dominated image of motherhood. They argued for the 
Szántó, Ildikó. "Hungarian Population Discourses in the Twentieth Century: The Problem of Declining Birth Rates." Hungarian Cultural Studies. e-Journal of the American Hungarian Educators Association, Volume 8 (2015): http://ahea.pitt.edu DOI: 10.5195/ahea.2015.215

autonomy of the individual and stood for a more progressive stance, but nevertheless for a pronatalist, national attitude, thus the women journalists' view on feminism and emancipation remained partial. Bozóky was among the first who advocated a significant increase of the family and child allowance, and higher paid maternal leave as well as flexible working hours for mothers (Bozóky1964c:3). In contrast to the pronatalist view, the non-populist women journalists argued that a single-child family or a family with two children did not necessarily imply an "anti-baby" attitude, but highlighted the financial burden of a larger family (László 1964:5, Erki 1964: 5-6).

In summarizing the first debate, a large number of populist participants dominated the discourse, who implied that the low birth is related to a declining national force as well as an implication of diminishing Hungarian presence in the Carpathian Basin. At the same time the populists emphasized the moral responsibility of the individual for the community at large and opposed a consumer oriented individualism in all spheres of life. In short, they tacitly questioned the socialist leadership of the political elite, and their criticism of the failure of socialist values was a hidden attack on those in power (Heller, Némedi and Rényi 1990: 25). The first debate coincided with the period of economic consolidation of the Kádár period, and the non-populists, first of all the economists amongst them, were baffled by the debate and therefore tended to ignore the ideological differences between pronatalist Marxists and non-Marxists. The demographer György Péter, the Head of the Hungarian Central Statistical Office, pointed out that the low birth rates were the result of modernization. Yet he also raised his voice when populists questioned the basic rights of an individual since he opposed the anti-abortionist stance (Heller, Némedi, and Rényi 1990: 23-25, Vitányi 1970:38).

The second population debate, in the 1970s, differed from the first in as much as there was less emphasis on the excesses of individual freedom contrary to socialist values, and these markedly expressed a national anxiety and a stronger, though still covert, criticism of government policies. There was much higher representation of demographers and non-populists in the discussions of the 1970s than earlier. Furthermore, the second population debate in the 1970s took place concurrently with several key events, such as the suppression of the Hungarian Economic Reform and of the New Left when the Budapest School of Marxist Humanism was dismembered. The temporary discontinuation of economic reforms added another dimension to the debate as anti-reformers often shared the same political platform with the pronatalists, while the pro-reformers, mostly non-Marxists, found themselves on the non-populist side (Heller, Némedi, and Rényi 1995: 134). However, both the populists and the Marxists, including the nonpopulists, partially shared the view on the importance of the family, but differed from the traditional outlook on gender relationships in their opposition to the authoritarian state (Heller 1970: 305, Vajda and Heller 1970: 1655). The populist participants of the second debate formed the majority again, dominated by the journalists, Fekete and Domonkos Varga of the "népi" circle. The public response to the "baby or a car" [kicsi vagy kocsi] discussion was overwhelming. The readers of the Nök Lapja ['Women's Weekly'] alone contributed over two thousand letters representing every strata of society (Fekete 1972: 357). At the same time, the introduction of the generous government population policy enacted in 1973 and a less liberal regulation for terminating pregnancies was welcomed by all. It was no doubt viewed as the result of populists' pressure. On the whole, the second population debate still focused on the national aspect of the low birth rate as the most important issue, whereas the writers were concerned about numbers. Another aspect emerged at this time, namely a middle class family image which pointed to the inequalities between large and smaller well-to-do families. 
Szántó, Ildikó. "Hungarian Population Discourses in the Twentieth Century: The Problem of Declining Birth Rates." Hungarian Cultural Studies. e-Journal of the American Hungarian Educators Association, Volume 8 (2015): http://ahea.pitt.edu DOI: 10.5195/ahea.2015.215

Concurrent with the debates on the low birth rate and its future implications, Illyés, the distinguished poet, expressed his anxiety in several poems, plays and numerous articles. $\mathrm{He}$ remained a dominant intellectual figure until his death, and was regarded as the living conscience of the nation. Illyés saw the family as the corner-stone of the nation and said that "whichever country which buries more than it brings forth does not think of its future, consumes its present and will ultimately devour itself" [Amelyik ország évenként több embert tesz sirba, mint bölcsőbe, az nem takarit a jővőre: feleszi a készt. Végül teljes önmagát] (Illyés 1967:705-706). Illyés echoed the populists' views of the 1930s, which was also supported by writers such as Veres, Moldova, and Géza Páskándi, who were just as concerned about the disappearance of the rural population (Veres 1964b:1609, Moldova 1987: 306, Páskándi 1982:5). Illyés was preoccupied by the possible long-term effect of low birth rate and was haunted by the vision of national death and the disappearance of the Hungarian language. The idea of the death of the nation, as well as the threat of being outnumbered by others had been ingrained in Hungarian literature since the end of the eighteenth century, and the poet invoked Herder's prophecy, that "of the Hungarians, small in number and wedged in between others, not even the language will be detectable as the centuries pass" [A mások közé ékelt kis számú magyaroknak századok múltán talán majd a nyelvét sem lehet fölfedezni] (Illyés 1977). He voiced this fear of the dissolution of national identity in one of his dramas, the Tiszták ['The Pure Ones'], which dealt with the loss of the cultural identity of the Cathars, who refused to abandon their language and beliefs. The annihilation of the Cathars also intended to draw a parallel to the plight of the Hungarian minority that was subjected to extreme nationalist policies under Ceausescu in Romania. One of his best known poems, "A Wreath" [Koszorú], is a declaration of love for the language and its limitations since it is spoken by barely fourteen million people, of whom one third live outside the political borders. Illyés believed that the primary duty of the poet was to answer the most troublesome questions of his time, and he could never divorce himself from national and public issues, whether it was the low birth rate, high suicide figures or minority rights (Illyés 1971: 6-7, Vajda 1977: 39-40, Domonkos 1983: 14, Illyés and Illyés 1994: 203).

The essential point of the third population debate in the 1980s was a more explicit, though still limited, criticism of the socialist system and its legitimacy. In the course of debates, the non-populists' views were best expressed by the sociologists Zsuzsa Ferge and Pál Tamás, and proved to be more controversial than the demographers' discourse. Ferge claimed that women had never had enough say in Hungary and pointed out the inequalities in wages, salaries, and career opportunities, in spite of official socialist doctrine. In addition, she argued that women should have a choice, though work and family commitments need not be opposed. She also questioned the essence of the population debate and the need to increase the number of live births, and disagreed with the notion that a gradual population loss could lead to a national disaster. Similarly to Ferge, Tamás emphasized the need for a value-oriented tolerant society over the notion of national decline (Wisinger1982:5, Tamás 1973:3-5, 1981:5). However, both populists and non-populists agreed that there should be a long-term population policy; open political criticism was warily espoused by the 1980s. The demographers reinstated their argument that the low birth rate was still part of the modernization process, which was also experienced in more advanced Western European countries (Andorka 1987: 284-294, Klinger and Monigl 1985: 25-33).

Following the 1989-1990 political and economic changes, the issue of the stagnating birth rate and the decreasing population seemed to lose its political significance. In the post-1990 
Szántó, Ildikó. "Hungarian Population Discourses in the Twentieth Century: The Problem of Declining Birth Rates." Hungarian Cultural Studies. e-Journal of the American Hungarian Educators Association, Volume 8 (2015): http://ahea.pitt.edu DOI: 10.5195/ahea.2015.215

years demographers advocated the need of a long-term population policy in order to improve demographic trends, which had remained unfavorable in the past thirty years. After 2010 the Orbán government consulted intellectuals and social scientists about the low fertility rates. Firstly, there was a general consensus on the importance of the issue, whilst at the same time the political criticism espoused earlier by the government lost its impetus. Secondly, as population growth declined on a national scale, racism resurfaced in the comparisons of Roma and nonRoma fertility rates. According to the result of the questionnaires, half of the responses welcomed and accepted a long-term population policy but also feared an intervention by the state in the private lives of its citizens (Faragó 1999: 138, Melegh 1999: 160).

By 2011, total population decreased to below ten million and the fertility rate was only 1.23 , one of the lowest in the EU, which again focused public attention on the continuously low birth rate and the forecasted impact of an aging population (Kapitány and Spéder 2012: 33, Hablicsek 1998: 472). In order to counteract the low birth rate figures, the current government introduced pronatalist measures as part of its political program favoring middle and high income earners with more than two children, and removed access to the "abortion pill" (RU-486), which is widely used in Europe and the USA. The new family policy was intended to boost fertility, but in fact it resulted in a redistribution of resources from poor to rich families, while the reinstituted three years of parental leave, kept women away from the workforce and strengthened patriarchal attitudes (Századvég 2014: 1, Szikra 2014: 494-495).

In the twentieth century, the discourse on the declining birth rate encompassed various strands of political ideologies, with differences between the intellectuals and the wider public, as well as among the demographers. The debates were linked to the impeded and uneven social development of Hungary, since the "national" or populists and democratic or progressive forces all took a different approach to the population issue.

From the beginning of such research, starting with Buday and evident throughout the interwar period, the population issue was both a philosophical and a political discourse. This pattern was also followed in the three major debates in the socialist period. In the interwar period, the populists or the "népi" writers viewed the people and first of all the peasantry as the nation. Their political and often anti-capitalist criticism fueled Hungarian nationalism as well as a critique of modernity. In contrast to the populists' arguments, the "urbanites" or liberals stressed the need for the democratization of the country as a means of progress over national issues. The differences between populists and non-populists re-emerged between the 1960s and the 1980s. The new populists, who were anti-individualists, anti-consumerists, traditionally family-centered, with a strong appeal to nationalism and critical of socialist politics, dominated the debates in the restricted public sphere in the pre-1990 era. In comparison, the non-populists, whether demographers or sociologists, who based their views on empirical data remained a minority in public opinion. The sharp intellectual divisions between the populists and the nonpopulists faded towards the end of the century but resurfaced by 1998, as populism and population policy became a manipulative tool of politics. In short, the various discourses on the issue of declining birth rate were used as a means of political and social criticism in twentieth century Hungary (Melegh 2006: 76). 
Szántó, Ildikó. "Hungarian Population Discourses in the Twentieth Century: The Problem of Declining Birth Rates." Hungarian Cultural Studies. e-Journal of the American Hungarian Educators Association, Volume 8 (2015):

\section{Works Cited}

Andorka, Rudolf. 1969. “A születésszám gazdasági és társadalmi tényezői Magyarországon” ['Economic and social factors of the birthrate in Hungary']. Valóság 3: 26-39.

- 1987. Gyermekszám a fejlett országokban. ['Determinants of Fertility in Advanced Countries']. Budapest: Gondolat Könyvkiadó.

—.2001. Gyermek, család, történelem. Történeti Demográfiai Tanulmányok. ['Child, Family,History. Historical Demograpahic Papers']. Budapest:Századvég.

Babits, Mihály. 1933. “Elfogy a magyarság?” ['Vanishing Hungarians?'] Nyugat 19: 269-271. Babus, Antal. 2002. "Illyés Gyula és Fülep Lajos az egyke Ellen. A Pusztulás" ['Gyula Illyés and Lajos Fülep Against the Egyke. Disapperance of Hungarians']. Studia Litteraria. ['Journal of Literature and Cultural Studies'] Debrecen, Tomus Vol.XL.: 26-34.

Bibó, István. 1982. "Magyar társadalomfejlődés" ['Hungarian Social Development']. In Bibó István Összegyüjiött Munkái 2 ['Collected Works of István Bibó 2']. Eds. István Kemény and Mátyás Sárközi. Bern: EPMSZ.

Bodó, Béla. 2001. "Progress or National Suicide: The Single-Child Family in Hungarian Political Thought, 1840-1945", Hungarian Studies Review. 1-2:185-208.

Bor, Ambrus.1963a.“Tizenhárom ezrelék” ['Thirteen Thousandth'] Kortárs 5: 721-731.

__ 1963b. "Több kenyér, kevesebb gyerek" ['More Bread, Less Children']. Élet és Irodalom ['Life and Literature'] 50:5.

Bozóky, Éva. 1964a. "Magánügy vagy a köz gondja?” ['Private or Public Responsibility?']. Élet és Irodalom ['Life and Literature'] 2:7-8.

—1964b. "Vita a népesedésről" [Debate About Population Growth]. Élet és Irodalom ['Life and Literature'] 5:5-6.

—. 1964c. "Négy kérdés és ötven válasz" ['Four Questions and Fifty Answers']. Élet és Irodalom ['Life and Literature'] 42:3.

Braun, Róbert. 1933. "A hivatalos satisztika” ['The official statistics']. Nyugat 19: 279-281.

Buday, Dezső. 1909. “Az egyke Baranya vármegyében” ['The Single-Child Family in Baranya County']. Budapest: Taizs.

—. 1909. "Az egyke” ['The Single Child']. Huszadik Század ['The Twentieth Century'] 2/38: 3-17.

Congdon, Lee. 1976. "Karl Polanyi in Hungary, 1900-1919." Journal of Contemporary History 11/1: 167-183.

Cseh-Szombathy, László. 1978. A változó család ['The Changing Family']. Budapest: Kossuth Kiadó.

Dányi, Dezső. 1960. “Az 1777 évi lelkek összeírása” ['The account of souls in 1777 ']. In Történeti Statisztikai Évkönyv ['Historical Satistical Yearbook']. Ed. Gyözö Ember. Budapest: SKV: 167-193.

— 1977. "Regionálsi fertilitási sémák Magyaroszágon a 19.százsad végén” ['Regional Fertility Patterns in Hungary at the end of the $19^{\text {th }}$ century']. Demográfia 20/1: 56-87.

Demény, Paul. 1972. "Early Fertility Decline in Austria-Hungary: A Lesson in Demographic Transition." East-West Population Institute. Reprint 25. Honolulu: East-West Center. Also in R. Revelle and D.V. Glass, eds. 1972. Population and Social Change. London: Edward Arnold: 153-172.

Domonkos, Mátyás. 1983. “A Poet Taking Sides.” The New Hungarian Quarterly. 91: 14-15. 
Szántó, Ildikó. "Hungarian Population Discourses in the Twentieth Century: The Problem of Declining Birth Rates." Hungarian Cultural Studies. e-Journal of the American Hungarian Educators Association, Volume 8 (2015):

Ember, Győzö. Ed. 1960. Történeti Statisztikai Évkönyv ['Historical Statistical Yearbook']. Budapest: SKV.

Erdei, Ferenc. 1973 [1938]. Parasztok ['Peasants']. Budapest: Akadémiai Kiadó. 1940. Magyar Falu ['Hungarian Villages']. Budapest: Athenaeum Kiadó. 1941. Magyar paraszttársadalom ['Hungarian Peasant Society']. Budapest: Franklin.

Erki, Edit.1964. “Ok vagy okozat?” ['Cause or Effect?']. Élet és Irodalom ['Life and Literature'] 12:5-6.

Faragó, Tamás. 1999. "Körkérédés a népesedésről” [“An all-round inquiry about population'] Demográfia 42/3-4: 138-159.

Féja, Géza. 1937. Viharsarok ['Stormy Corner, the description of Békés, Csongrád and CsanádArad-Torontál counties']. Budapest: Atheneum. . 1984. Magyar Haláltánc ['The Hungarian Dance of Death’]. Budapest: Szépirodalmi Könyvkiadó.

Fekete, Gyula. 1964. "Árnyékbokszolás" ['Shadow boxing']. Élet és Irodalom ['Life and Literature']. 1964/13:5-6. . 1967. "Ki fizesse meg az utódnevelés költségeit?" ['Who Should Pay for the Future Generation?'] Élet és Tudomány ['Life and Science'] 1:14. - Ed. 1972. Éljünk magunknak? ['Should We Live For Ourselves?’]. Budapest: Szépirodalmi Könyvkiadó.

Fülep, Lajos. 1929.“Riport és cikkek” ['Reports and articles']. Pesti Napló [Pest Journal] 10th November, 17th November, 26th November 1929, 4th December, 15th December 1929. . 1933. "Mit mond a szemtanú" ['What Does The Witness Say']. Nyugat 19:281-287.

Hablicsek, László. 1998. "Demográfiai forgatókönyvek, 1997-2050” ['Demographic Scenarios, 1997-2050']. Demográfia. 4: 472-495.

Heller, Ágnes. 1970. "A nemek közötti kapcsolat jövőjéröl” ['Future Gender Relationship']. Kortárs 2: 301-308.

Heller, Mária, Dénes Némedi and Ágnes Rényi. 1990. "Népesedési viták Magyarországon 1960-1986” ['The Demogrpahic Debates 1960-1986’]. In KSH Népességtudományi Kutatóintézetének jelentései 37 ['Reports of the Hungarian Central Statistical Office Demogrpahic Insitute 37']. Budapest: KSH: 13-125. - 1995. "Populist Discursive Strategies under State Socialism: The Demographic Debates." The Journal of Popular Culture 2: 129-141.

Hidvégi, János. 1938. Hulló magyarság ['Vanishing Hungarians']. Budapest: Athenaeum. Hölbling, Miksa. 1845. Baranya vármegyének orvosi helyirata ['The Medical Survey of Baranya County']. Pécs: Lyceumi Könynyomó Intézet.

Hőke, Lajos. 1872. "A baranyai Ormányság” ['The Ormánys of Baranya']. Hazánk és Külföld ['Our Country and Foreign Lands']. Pest: Athenaeum Részvénytársaság

Illyés, Gyula. 1933. "Pusztulás. Úti jegyzetek. Észak-Baranya" ['Devastation: Travelling Notes in Northern Baranya'] Nyugat combined issue 17-18: 189-205.

. 1933. "A magyarság pusztulása" ['Disapperance of Hungarians']. Nyugat 1933.20: 337-344.

. 1938. Magyarok: Naplójegyzetek II. ['Hungarians.Travel notes']. Budapest:Nyugat. . 1966. "Egy körkérdés tanulságai" ['The Results of An All-Round Inquiry']. Népszabadság [Daily paper of the Hungarian Socialist Workers Party] 1966,21 ${ }^{\text {st }}$ April .1967. "Egy körkérdés tanulságai" ['The Results of An All-Round Inquiry']. In Poharaim. Összegyüjtött versek. ['Collected Poems’]. Budapest: Szépirodalmi Kiadó. 
Szántó, Ildikó. "Hungarian Population Discourses in the Twentieth Century: The Problem of Declining Birth Rates." Hungarian Cultural Studies. e-Journal of the American Hungarian Educators Association, Volume 8 (2015):

1971. Hajszálgyökerek. Esszék, interjúk. ['Collection of Essays and Interviews'] Budapest: Szépirodalmi Könyvkiadó.

. 1971. Tiszták ['The Pure Ones']. In Négy dráma ['Four Dramas']. Budapest: Magvető: 195-294.

—. 1977. "Válasz Herdernek és Adynak" ['A Reply to Herder and Ady]. Magyar Nemzet ['Hungarian Nation', a daily paper]. 25 $5^{\text {th }}$ December 1977 and 1st January 1978. . 1993. [1936]. Puszták népe ['People of the Puszta']. Budapest: Századvég Kiadó.

Illyés, Gyuláné and Illyés, Mária.1994. Naplójegyzetek ['Diary Notes']. Budapest: Századvég.

Jászi, Oszkár. Ed. Huszadik Század ['The Twentieth Century'].1909.2. 38. 3-17.

Jobbágy, Károly.1964. "Ezer év" ['Thousand Years']. Élet és Irodalom 6:5.

Kapitány, Balázs and Zsolt Spéder. 2012. Demographic Portrait of Hungary 2012: Report on the Conditions of the Hungarian Population, Fertility. Budapest: Hungarian Central Statistical Office (HCSO).

Kemény, István, and Mátyás Sárközi. Eds.1982. Bibó István Összegyüjtött Munkái 2 ['Collected Works of István Bibó 2'] Bern: EPMSZ.

Kiss, Géza. 1986. [1937]. Ormányság. Budapest: Gondolat Kiadó.

Klinger, András. 1964. "Differenciális termékenység" ['Differential Fertiltiy']. In Bevezetés a demográfiába ['Introduction to the Demogrpahy']. Ed. Egon Szabady. Budapest:

Közgazdasági és Jogi Könyvkiadó: 280-292.

Klinger, András, and István Monigl. 1985. "Gondolatok népesedéspolitikánk távlati koncepciójáról” [ 'Long-Term Conceptions of Population Policy']. Társadalmi Szemle. 11: 25-33.

Kodolányi, János. 1922. "Sötétség” ['Darkness']. Nyugat: 1922:17-18:1076-1090.

—. 1987. Reprint [Élöszó.1927. 2-3. szám. 49-63.] "A hazugság öl” ['Lying Kills' ].Budapest:Magvető. . 1963.[1941]. Baranyai utazás ['Travel to Baranya County']. Budapest: Magvető.

Kodolányi, János and János Kodolány, Jr. 1979. Második baranyai utazás ['Second Travel to Baranya County']. Pécs: Baranya Megye Tanácsa.

Kókay, György. Ed. 1979. A magyar sajtó története1705-1848 ['The History of the Hungarian Press']. Budapest: Akadémiai Kiadó.

Kovács, Alajos. 1923. "Az egyke és a népszaporodás" ['The Single Child and Population Growth']. Magyar Statisztikai Szemle ['Hungarian Statistical Review'] 3-4: 65-79.

Kovács, Imre. 1937. A néma forradalom ['The Silent Revolution']. Budapest: Cserépfalvi.

_ 1940. A parasztéletforma csödje ['The Peasant Way of Life: Doomed']. Budapest: Bolyai Akadémia.

KSH Népességtudományi Kutatóintézet ['Hungarian Central Statistical Office Demogrpahic Insitute']. 1978. Demographic Yearbooks of 1960-1978. Budapest: KSH.

László, Anna. 1964. "Koraszülés" ['Premature Births']. Élet és Irodalom ['Life and Literature'] 1964/ 5:5.

Lendvai, Paul. 2002. The Hungarians. A Thousand Years of Victory in Defeat. London: Hurst and Company.

Litván, György, and László Szüics. Eds. 1973. A szociológia első maygar mühelye ['The First Workshop of Hungarian Sociology']. Budapest: Gondolat.

Lőcsei, Pál. Ed. 1971. Család és házasság a mai magyar társadalomban ['Family and Marriage in Contemporary Hungarian Society']. Budapest: Közgazdasági és Jogi Könyvkiadó.

Melegh, Attila. 1999. “Ki mitől fél?” ['Who is Afraid of What?'] Demográfia 42/3-4: 160-170. 
Szántó, Ildikó. "Hungarian Population Discourses in the Twentieth Century: The Problem of Declining Birth Rates." Hungarian Cultural Studies. e-Journal of the American Hungarian Educators Association, Volume 8 (2015):

2006. On the East-West Slope: Globalization, Nationalism, Racism and Discourses on Eastern Europe. Budapest: Central European University Press.

Moldova, György. 1987. Az Örség panasza [‘The Grievances of Örség']. Budapest: Magvetö.

Páskándi, Géza. 1982. "A tudat 'lakáskérdései” [‘The Consciousness of Home’]. Élet és Irodalom ['Life and Literature'] 1982/1: 5.

Pezenhoffer, Antal. 1922. A demográfiai viszonyok befolyása a népszaporodására ['The Impact of Demographic Relations on the Increase of the Popualtion']. Budapest: Pallas Részvénytársaság nyomdája.

Potó, János. 1986. "A kommunizmus igérete. Életmód viták az 1960-as években" ['The Promise of Communism: The Way of Life Debates in the 1960s']. História. 5/6: 26-29.

Ránki, György. Ed. 1978. Magyarország Története 1918-1919, 1919-1945 ['History of Hungary']. Budapest: Akadémiai Könyvkiadó.

Romsics, Ignác. 1999. Magyarország Története a XX. Században ['History of Hungary in the Twentieth Century']. Budapest: Osiris.

Schöpflin, Aladár. 1933. "A nép, a nyelv és a föváros" ['The people, the language and the capital city']. Nyugat 19: 272-273.

Szabady, Egon. 1961. "Magyarország népességének foglalkozási összetétele” ['Occupational structure of Hungary's population']. Demográfia 4:7-34.

. Ed. 1964. Bevezetés a demográfiába ['Introduction to the Demogrpahy']. Budapest: Közgazdasági és Jogi Könyvkiadó. . 1971. "A magyar családok demográfiai sajátosságai" ['Demographic characteristics of Hungarian families']. In Család és házasság a mai magyar társadalomban ['Family and Marriage in Contemporary Hungarian Society']. Ed. Pál Lőcsei. Budapest: Közgazdasági és Jogi Könyvkiadó.

Szabó, Zoltán. 1937. A tardi helyzet ['The Situation in Tard']. Budapest: Cserépfalvi.

—. 1938. Cifra nyomorúság ['Gaudy Misery']. Budapest: Cserépfalvi.

Szántó, Ildikó. 2014. "Problems of a Declining Hungarian Birth Rate: A Historical Perspective." Hungarian Cultural Studies 7: 93-109.

Századvég Foundation. 2014. "Focus on the Family in Focusing on Hungary." Budapest: Századvég Kiadó.

Széchenyi, Imre. 1906. Az egyke ['The Single Child']. Budapest: S.n.

Szikra, Dorottya. 2014. "Democracy and Welfare in Hard Times: The Social Policy of the Orbán Government in Hungary between 2010 and 2014." Journal of European Social Policy 24/5: 486-500.

Tamás, Pál. 1973. "Népesedés, népesedéspolitika" ['Population Growth, Population Policy']. Palócföld 4: 3-5.

—.1981. "Demográfiai hadiállapot?” ['Demographic Hostilties?']. Élet és Irodalom ['Life and Literature'] 1981/7:5.

Vajda, Mihály, and Ágnes Heller. 1970. "Családforma és kommunizmus" ['Family and Communism']. Kortárs 10: 1655-1660.

Vajda, Miklós, Ed. 1977. Modern Hungarian Poetry. Budapest: Corvina Press.

Vas, István. 1984. Nehéz szerelem. Miért vijjog a saskeselyü? ['Difficult Love: Why Does the Vulture Screech?']. Budapest: Szépirodalmi Könyvkiadó.

Veres, Péter. 1964a. "A születésszabályozás" ['Birth Control'] Élet és Irodalom 1964/11: 5. . 1964b. "Tervgazdaság és népesedés-politika" ['Economic Planning and Population Policy']. Kortárs 11: 1608-1618. 
Szántó, Ildikó. "Hungarian Population Discourses in the Twentieth Century: The Problem of Declining Birth Rates." Hungarian Cultural Studies. e-Journal of the American Hungarian Educators Association, Volume 8 (2015): http://ahea.pitt.edu DOI: 10.5195/ahea.2015.215

Vezér, Erzsébet. Ed. 1977. Ady Endre Publicisztikai Irásai 1905-1907. 2.kötet ['Journalism of Endre Ady, 1905-1907 Vol. 2']. Budapest: Szépirodalmi Könyvkiadó.

Vitányi, Iván. 1970. "Ideológiai Vallomások” ['Ideological Statements']. Valóság 7: 38.

Wisinger, István. 1982. "Kényszer vagy felismerés? Beszélgetés a nők helyzetéről, Ferge Zsuzsával " ['Coercion or realization? Talking to Zsuzsa Ferge about the situation of women']. Élet és Irodalom ['Life and Literature'] 1982/5:5. 